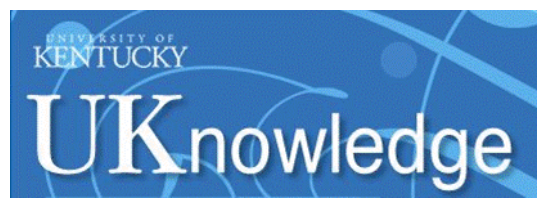

University of Kentucky

UKnowledge

$6-2010$

\title{
Ethics, Empathy, and the Education of Dentists
}

David A. Nash

University of Kentucky, danash@uky.edu

Follow this and additional works at: https://uknowledge.uky.edu/ohs_facpub

Part of the Bioethics and Medical Ethics Commons, and the Dental Public Health and Education Commons

Right click to open a feedback form in a new tab to let us know how this document benefits you.

\section{Repository Citation}

Nash, David A., "Ethics, Empathy, and the Education of Dentists" (2010). Oral Health Science Faculty Publications. 20.

https://uknowledge.uky.edu/ohs_facpub/20

This Commentary is brought to you for free and open access by the Oral Health Science at UKnowledge. It has been accepted for inclusion in Oral Health Science Faculty Publications by an authorized administrator of UKnowledge. For more information, please contact UKnowledge@lsv.uky.edu. 


\section{Ethics, Empathy, and the Education of Dentists}

Notes/Citation Information

Published in Journal of Dental Education, v. 74, no. 6, p. 567-578.

Reprinted by permission of Journal of Dental Education, Volume 74, 6 (June 2010). Copyright 2010 by the American Dental Education Association. http://www.jdentaled.org 


\title{
Ethics, Empathy, and the Education of Dentists
}

\begin{abstract}
David A. Nash, D.M.D., M.S., Ed.D.
Abstract: Professional education in dentistry exists to educate good dentists - dentists equipped and committed to helping society gain the benefits of oral health. In achieving this intention, dental educators acknowledge that student dentists must acquire the complex knowledge base and the sophisticated perceptual-motor skills of dentistry. The graduation of knowledgeable and skilled clinicians in dentistry is a necessary, but not sufficient, condition for ensuring quality oral health care. The further requirement is the commitment of graduates to applying their abilities with moral integrity: providing appropriate and quality care in their patients' best interest. Ultimately, good dentistry depends on individuals committed to treating their patients and society fairly, that is, ethically. This essay describes the historical basis for thinking about ethics from the perspective of human nature; describes how evolutionary ethics seeks to ground moral behavior in human emotion rather than primarily human reason; discusses the roots of morality in the behavior of animals, behavior that observed in humans would be described as empathy; characterizes empathy, discussing its imperative in caring for patients; and suggests what implications an empathy-mediated understanding of morality has for dental education.
\end{abstract}

Dr. Nash is William R. Willard Professor of Dental Education and Professor of Pediatric Dentistry, College of Dentistry, University of Kentucky. Direct correspondence and requests for reprints to him at College of Dentistry, University of Kentucky, 800 Rose Street, Lexington, KY 40536-0297; 859-323-2026 phone; 859-323-4685 fax; danash@email.uky.edu.

Keywords: ethics, morality, empathy, evolutionary biology, dental education

Submitted for publication 11/19/09; accepted 1/21/10

$\mathrm{P}$ rofessional education in dentistry exists to educate good dentists - dentists equipped and committed to helping society gain the benefits of oral health. In achieving this intention, dental educators acknowledge that student dentists must acquire the complex knowledge base and the sophisticated perceptual-motor skills of dentistry. The graduation of knowledgeable and skilled clinicians in dentistry is a necessary, but not sufficient, condition for ensuring quality oral health care. The further requirement is the commitment of graduates to applying their abilities with moral integrity: providing appropriate and quality care in their patients' best interest. Ultimately, good dentistry depends on individuals committed to treating their patients and society fairly, that is, ethically. Thus, leaders in the health professions and dental education have, over the past few decades, begun to emphasize the importance of professional ethics in the curricula of those who are being educated to care for the health of the public.

Evolutionary psychology, the relatively recent focus on understanding human behavior based on evolutionary biology and cognitive neuroscience, forces new understandings regarding the basis and motivation for moral behavior. Heretofore, ethics has been understood and taught assuming that humans are by nature asocial and inherently selfish, and only behave morally based on a rationally informed enlightened self-interest. Empirical evidence indicates that humans have biologically evolved an empathic nature. Evolutionary ethics grounds human morality in empathy. Understanding moral behavior from this biological perspective has implications for the goal in dental education of developing good dentists.

By exposing the historical basis of understanding ethics from a naturalistic account of human nature, it is possible to understand how evolutionary ethics seeks to establish human empathy as a foundation for moral behavior. By discovering the roots of morality in the behavior of other animals, it is possible to understand how moral behavior can be better understood in humans in terms of empathy, rather than simply rational reflection, or religious or social norms. This will provide a basis for characterizing empathy and demonstrating how it is a moral imperative in caring for patients. Finally, it will also provide a basis for understanding what implications an empathy-mediated understanding of morality has for dental education. 


\section{A Naturalistic Ethics in Historical Context}

Ethics is that branch of the discipline of philosophy that studies morality. ${ }^{1}$ It is the "science" of the moral. ${ }^{2}$ Ethics seeks to answer the question "How should I behave?" Morality is about behavior in the social interaction of humans. Behaviors have consequences, and can be evaluated as "good" or "bad" using reasoned, objective criteria. Ethics is reflection on goodness and badness, right and wrong, virtue and vice, oughts and ought nots, and ends and means. The distinction between ethics and morality is the distinction between the object of study (morality) and the study itself (ethics). Ethics is ultimately about norms for human social cooperation.

Contemporary ethical theory is increasingly becoming "naturalistic," rooted in an understanding of evolutionary biology, as well as cognitive neuroscience. ${ }^{3-12}$ However, ethical theory based in humans' biological nature can be traced from Aristotle through David Hume, Adam Smith, and Charles Darwin to the present. A brief review of these four giants of intellectual history, as well as those with a different foundation for their moral theory, will be addressed before documenting the support of contemporary science for an empirical approach to ethics and an explication of the role that empathy plays in such an ethical theory - with empathy being understood as the capacity to enter into the emotional/cognitive world of another and thereby vicariously have a sense or appreciation of what he or she is experiencing. A more thorough discussion of empathy will follow.

Aristotle held that humans are by nature social animals: humans are not hermits. ${ }^{13}$ As all animals, humans have needs that translate into desires - natural desires. Aristotle's naturalistic ethics is an ethics of desire. Desires provide the motivation to action. Aristotle said, "Thought by itself moves nothing." Desires are rooted in the emotions. Natural desires are human goods. However, as humans live in a social context, desires must be managed in order that a civil society can be achieved. Ethics then is the use of reason to determine how to rightly pursue that which is by nature desired. For Aristotle, the goal of human life is eudemonia, or well-being/happiness. Human flourishing exists when human desires are habituated to seek fulfillment according to the human constitution. Reason, for Aristotle, is that which acknowledges that certain behavioral characteristics, which he identified as virtues, are important if one is to be able to fulfill one's natural needs and desires in a social context. Aristotle's ethics is naturalistic in that he affirms humans are constituted as biological organisms and that biology is basic to both understanding and regulating behavior. Thomas Aquinas, the medieval theologian, in his explication of a natural moral law in the Summa Theologica, followed Aristotle in believing that moral behavior is the expression of a natural (innate) tendency. ${ }^{14,15}$

David Hume, the Scottish philosopher, contributed to an understanding of an ethics grounded in human nature. In An Enquiry Concerning Human Understanding, published in 1748, Hume agreed with Aristotle that one is not motivated to action by reason alone, but rather requires the input of the passions (emotions). ${ }^{16}$ In keeping with Aristotle's statement that "thought by itself moves nothing," Hume stated: "Reason alone can never be a motive to any action of the will." In another expression of this view, he wrote, "Reason is and ought only to be, slave to the passions." In this he is not promoting irrationality, but rather expressing the view that reason can direct action but not motivate it. Hume's mentor, Francis Hutcheson, had helped Hume understand the existence of an innate, emotion-based, empathy-mediated moral sense in humans, with the moral sense being understood as being able to distinguish right from wrong behavior. ${ }^{17}$

In The Theory of Moral Sentiments, Adam Smith, Hume's friend and colleague, known as the father of marketplace economics, joined Hume in affirming the importance of sympathy/empathy, along with rational self-interest, in the moral life. ${ }^{18}$ Smith wrote of the "fellow-feelings" one has for another: "Whatever is the passion which arises from any object in the person principally concerned, an analogous emotion springs up, at the thought of the situation, in the breast of every attentive spectator." These eighteenth-century thinkers helped set the philosophical stage for understanding that moral behavior is grounded in the human emotion of empathy, as science is increasingly illuminating.

Charles Darwin's epic On the Origin of Species, published in $1859,{ }^{19}$ was followed in 1871 by The Descent of Man, in which Darwin devoted several chapters to the issue of the origin of human morality. ${ }^{20}$ He opens Chapter IV with these words: "Of all of the differences between man and the lower animals, the moral sense or conscience is by far the most important. ... it is summed up in that short but imperious word ought." He continues by saying that "any animal whatever endowed with well-marked social instincts, 
the parental and filial instincts being here included, would inevitably acquire a moral sense or conscience, as soon as its intellectual powers had become as well developed, or as nearly well developed, as in man." In this statement, Darwin reaffirms Aristotle in stating that man is a social being and, as such, has instincts that support sociality. By instincts, he is referring to innate, genetically based dispositions. Important among these social instincts is sympathy or, as it is more recently expressed, empathy - the ability to place oneself emotionally/cognitively in the position of another. The literature of empathy discusses the interactivity between "emotional" and "cognitive" aspects of empathy, with the dimension of emotional empathy being understood as sharing feelings comparable to those being experienced by the other, and the cognitive aspect of empathy as intellectually taking the perspective of the other. Our sociality stems from our need for one another in order to survive and thrive. The promulgation of our species requires a heavy investment in child rearing - the cooperation of parents in the rearing of offspring. This is due primarily to our large brains and the extended period of dependency necessary for physical and cognitive maturation. Cooperation with other humans is a requirement of social living. For Darwin, the deeply abiding social instincts provide a basis upon which rational, conventional norms are subsequently based. Darwin demonstrates how a constitutional moral sense, based on empathy, could have evolved through natural selection. ${ }^{20}$

In contrast to the naturalistic orientations of Aristotle, Hume, Smith, and Darwin, many philosophers and theologians have understood humans to be asocial. Humans have been understood to be potentially moral as a result of rational reflection, but not naturally so. A classic philosophical statement of humanity's base nature was by the seventeenth-century English philosopher Thomas Hobbes in Leviathan. ${ }^{21}$ Hobbes considered what life would be like in a "state of nature." He imagined a state in which there were no acknowledged rules of morality, no laws, no police, no courts, and no government. In such a circumstance he said there would be an equality of need, scarcity of resources, and essential equality of human power, and all would be selfish — attempting to survive. The conclusion of his analysis constitutes a famous sentence in intellectual history. He said that such a state would result in "a constant state of war, of one with all . . . where life is solitary, poor, nasty, brutish, and short." Thus, Hobbes believed that man became a social being, with the attendant social contract of rules and governmental enforcement of laws, as an expediency - that humans are inherently asocial. Immanuel Kant made similar assumptions regarding human nature, arguing that moral behavior must be based on human reason and believing that human emotion is morally unreliable. ${ }^{22}$ For Kant, once reason determines that which is right from that which is wrong, then rules and laws can be developed in an attempt to guide human behavior. Human morality is based on man's rationality, not on an evolved moral sense rooted in empathy.

Social contract and rationalist philosophers stand in contrast to naturalistic moral sense thinkers. These two contrasting philosophical positions create a tension between understanding human morality as a system of rules imposed as a result of humans' cognitive reflection or a biologically evolved mechanism of cooperative social living with a foundation in empathy.

\section{Evolutionary Ethics}

In 1975, E.O. Wilson published Sociobiology: The New Synthesis..$^{23}$ In it he advocated the systematic study of the biological basis of all social behavior. Though almost the entire book is devoted to understanding the social behavior of animals (ethology), the last chapter generated considerable note as Wilson advocated that the science of studying the biological basis of the social behavior of other animals also be applied to studying the social behavior of the human animal. His work has contributed to the rapidly growing discipline of evolutionary psychology, the study of human behavior in the context of man's evolutionary history. ${ }^{24-26}$

Wilson went so far as to indicate that even human moral behavior is grounded in our evolutionary roots, as Darwin had suggested before him. He stated that biology, not philosophy, explains ethics "at all depths." He went on to say that "the time has come for ethics to be removed temporarily from the hands of philosophers and biologicized." ${ }^{23}$ This biologization of ethics results in a further refinement of the tradition of naturalistic ethics - an understanding that moral behavior, like all behavior, is ultimately understood in the context of humans' evolutionary heritage, a history that fostered taking the perspective of the other as critical to one's own survival and flourishing. Over the past few decades, new understandings of human behavior have developed based on ethology, suggesting that a disposition to moral behavior of humans is 
rooted in our basic animal nature. As a consequence, biologists and cognitive neuroscientists are enabling us to understand moral behavior from a naturalistic perspective and thus playing a role in thinking about ethics. As previously indicated, ethics is increasingly being understood in evolutionary context.

Richard Dawkins in his popular and classic The Selfish Gene, published in 1976, suggested that while we are programmed by "selfish genes" whose only "goals" are to replicate, "we, alone on earth, can rebel against the tyranny of the selfish replicators."27 Dawkins, though an evolutionary biologist, holds a view similar to Hobbes and Kant: that humanity is basically selfish and asocial, but can overcome this natural condition and choose to be moral based on cognitive reflection on right and wrong behavior in the context of one's enlightened self-interestmaking an intellectual commitment to choosing right over wrong.

In his Tanner Lectures at Princeton University in 2004, Frans de Waal referred to the approach of such thinkers as Hobbes, Kant, and Dawkins as "veneer theory." ${ }^{28}$ By that he means they argue for humans' overcoming their basic antisocial, amoral, and egoistic passions through ethical and/or spiritual reflection. An ethologist, de Waal has been influential in focusing attention on studies of primate behavior to achieve a better understanding of how human morality could have emerged as a result of evolutionary forces promoting cooperation among our ancestors. ${ }^{29-31}$

To understand human morality as based on evolutionary biology, it must be acknowledged that, from a purely biological perspective, the goal of the human organism is to have its genes expressed in another generation. ${ }^{32,33}$ Natural selection cares primarily not about us, but about our genes being promulgated. Understanding this, William Hamilton wrote what has become one of the most cited papers in evolutionary thought, "The Genetical Evolution of Social Behaviour," published in the Journal of Theoretical Biology. ${ }^{34}$ In it, he provided the theoretical basis for understanding what has come to be known as inclusive fitness or kin selection. He demonstrated that helping (altruistic) behaviors - that is, behaviors that are performed at some cost to the individualare more likely to be performed by a person if the receiver of the helping behavior is genetically related and that the propensity to do so is directly related to the degree of shared genes. Thus, one is twice as likely to help full siblings with whom they share half of their genes as they are to assist nieces, nephews, aunts, and uncles, with whom they share one-fourth of their genes. While it is "genetically beneficial" to help a close relative, the willingness to help is not unlimited. The concept of inclusive fitness provides the biological basis for understanding the devotion parents have for their children. And, as Darwin pointed out, those parental and familial instincts, now understood to be based in evolutionary genetics, are what have resulted in a moral sense grounded in the emotion of empathy.

In 1971, Robert Trivers introduced the theory of reciprocal altruism to explain in evolutionary terms why an organism would help another, other than a genetic relative. ${ }^{35}$ Reciprocal altruism is a form of helping behavior in which one organism provides a benefit to another at some degree of cost to the benefactor, without an immediate return of a benefit of comparable value. However, the benefit provided must at some future point in time be reciprocated. If not, the benefactor will usually withdraw any further helping act. An example of reciprocal altruism in dental education would be if one member of the faculty assisted another in a research endeavor and then was subsequently assisted in his or her own research by the individual originally benefitted. A failure of reciprocal altruism would be if student dentist $\mathrm{A}$ helped student dentist B study for a biochemistry test, but student dentist B subsequently refused to help student dentist A study for an examination in pediatric dentistry.

The concept of reciprocal altruism has been validated in game theory by Robert Axelrod in his use of the prisoner's dilemma game in The Evolution of Cooperation. ${ }^{36}$ The prisoner's dilemma demonstrates that successful cooperation in a social setting is the result of reciprocal altruism. The most beneficial strategy is always to be cooperative: that is, to help others, expecting to be helped in return. If one does not reciprocate, then further helping behavior is or should be discontinued. This successful strategy has been designated "tit for tat." To continue to cooperate with one who does not reciprocate cooperation is to be taken for a sucker. From an evolutionary perspective, our ancestors who were cooperative with others survived and passed their cooperative genes on to a new generation; those who did not learn to cooperate did not survive. Thus, cooperation through reciprocal helping became the norm for humans.

The evolutionary psychologist David Barash, in his book The Survival Game, offers a detailed account of how game theory explains the biological basis of cooperation and competition. ${ }^{37}$ In the context 
of this discussion, it is important to acknowledge that humans house a Stone Age brain in a contemporary world. ${ }^{38}$ The homo sapien brain evolved in an environment much different from that in which humans live today. Designated the Environment of our Evolutionary Adaptation (EEA), ${ }^{39}$ humans lived in hunter-gatherer bands of 150-200 individuals, many of whom were genetically related to one another. ${ }^{32}$ Even if unrelated, individuals had contact with others in the band on a regular basis. These two circumstances permitted the evolution of the concepts of kin selection and reciprocal altruism as a natural means of cooperating for the good of all, that is, morality. However, contemporary humans do not live in such an environment. Many, if not most, of our interpersonal transactions are with "moral strangers." Thus, the thinking of Hobbes, Kant, and Dawkins, mentioned earlier, is relevant. In an environment of moral strangers, the nature of human interaction changes: individuals are more likely to defect from cooperation based on empathic, reciprocal altruism. Thus, rules of cooperation based on a rational enlightened self-interest and laws enforceable by government become imperative to sanction defectors. Axelrod has demonstrated that cooperative behavior will evolve naturally through an interactive society, as individuals learn that "cooperators" are more successful in life's circumstances than are "defectors." It is in one's enlightened self-interest to cooperate by being moral.

Empathy provides the basis for the concept of morality. Some version of the Golden Rule, "Treat others as you would want to be treated," is core to the moral code of essentially every culture or religion including Greek polytheism, ${ }^{40}$ Judaism, ${ }^{41}$ Christianity, ${ }^{42}$ Islam, ${ }^{43}$ Hinduism, ${ }^{44}$ Confucianism, ${ }^{45}$ and Buddism. ${ }^{46}$ This rule is a statement of an ethics of reciprocity. It would not be possible to expect one to follow such a precept absent the ability to conceive the other as if he or she were the other. Developing skills of emotional/cognitive perspective-taking would provide competitive advantages and therefore would be naturally selected.

The codification of morality in rules such as don't kill, don't steal, don't lie are grounded in empathy - not harming another because one understands what it would be like to be harmed in that way. Morality is about cooperation: cooperating with one another in order to survive and thrive. The moral rules are rules of cooperation. Cooperation requires that I not harm you and you not harm me. The Dartmouth College philosopher Bernard Gert has summarized the moral rules as "do not harm others." ${ }^{\text {"47,48 }}$ As de Waal states, "moral rules tell us when and how to apply our empathic tendencies, but the tendencies themselves have been with us since time immemorial." ${ }^{11}$ Cooperation requires helping behaviors: I help you and you help me. As de Waal also has written, "Evolution favors animals that assist each other if by doing so they achieve long-term benefits of greater value than the benefits derived from going it alone and competing with others." ${ }^{\prime 49}$ We help others both because we empathize with their circumstance and because we know that at another time we will likely need their help. If we do not help them, they cannot be counted on to help us. Reciprocity is a key element of cooperative social life and is basic to the moral life; it is rooted in empathy. When Confucius was asked what one word could be used to summarize the moral life, he replied, "Reciprocity."45

\section{Empathy}

The literature regarding the concept of empathy is extensive. ${ }^{50-54}$ General conclusions can be drawn from the literature that permit advancing the importance of the concept of empathy to dental education and the profession of dentistry.

The English word "empathy" only came into common usage in the twentieth century. ${ }^{54}$ The term "sympathy" had been used previously to refer to what is today understood as empathy. Sympathy is now understood in a more restrictive sense of feeling sorry for someone or pity. "Empathy," on the other hand, is a transliteration of the ancient Greek word empatheia, literally, "[in] passion." 55 Thus, integral to the concept of empathy is to have within oneself a feeling being experienced by another. Adam Smith expressed it as "changing place in fancy [i.e., imagination]." 18 Contemporary use of "empathy" has been traced to the German philosopher and art historian Robert Vischer, who used the German term Einfühlung, literally "feeling into," to describe the feelings elicited in viewing works of art. ${ }^{56}$ Subsequently, Sigmund Freud used the term to describe the psychodynamics of putting oneself in another person's position. ${ }^{57} \mathrm{Carl}$ Rogers, the originator of patient- or client-centered therapy, defined empathy as the ability "to perceive the internal frame of reference of another with accuracy as if one were the other person, but without ever losing the as if condition" 58 (emphasis added). Rogers's "as if" suggests that empathy involves taking the perspective of the other. Our advanced 
cognitive and cultural development today reinforces the notion that it is in an individual's ultimate selfinterest to take into consideration the perspective of the other. Successful social living requires such "emotional intelligence."

Empathy evidently has a long history in mammalian evolution. In studies by Masserman and Wechkin, rhesus monkeys in a cage refused to pull a chain that provided them with highly desirable food when they discovered that doing so shocked another monkey in an adjoining cage. ${ }^{61}$ The researchers found that the desire to not inflict pain was stronger between monkeys who were familiar with one another versus those who were not. A highly publicized case of animal helping behavior, based on the needs of another, was the case of Binti Jua, a female gorilla who rescued a three-year-old boy who had fallen into the gorilla enclosure at the Brookfield Zoo in Chicago in August 1996. ${ }^{31}$ Numerous other examples of empathic behavior have been documented in animals. ${ }^{31,62,63}$

Empathy probably evolved based on the parental care that is required for the development of all mammals. ${ }^{19,64}$ During mammalian evolution, females who were responsive to the appeals of their infants for nurturance were more successful in transmitting their genes to a new generation than those who were less responsive. Mammals living in groups would have also supported the development and evolution of empathy. Group living requires cooperation in order for individuals within the group to survive, given the hostility of the environment. Empathy would have supported the cooperation of social mammals, facilitated their survival, and resulted in the transmission to a new generation of "empathic genes" that facilitated cooperation. As social psychologist Martin Hoffman has said, empathy is "the spark of human concern for others, the glue that makes social life possible." ${ }^{52}$ Hoffman argued, as early as 1981 , that empathy emerged as a result of natural selection. ${ }^{65}$

Recent studies support a genetic basis for empathy. Empathy is the opposite of autism. Simon Baron-Cohen has written extensively on the topic of autism and has characterized it as "blind-mindness." 66 Individuals falling on the autism spectrum are unable to sense or understand the emotions or feelings of another; they are blind to them. As a consequence, individuals with autism are challenged to function in a social environment. To varying degrees they lack the capacity for empathy. Baron-Cohen and his colleagues at Cambridge University have identified twenty-seven genes that are associated with autistic and/or empathy characteristics. ${ }^{67} \mathrm{~A}$ recent study of mice conducted jointly by researchers at the University of Wisconsin and Oregon Health \& Science University also found genetic evidence for empathic responses. ${ }^{68}$

Baron-Cohen has developed an empathizingsystemizing theory based on his research on autism. Using validated instruments to measure empathy and systemizing, he found that significantly more females had an "empathic brain" versus males and males a more "systemizing brain" versus females. ${ }^{69} \mathrm{He}$ hypothesizes that systemizing was an evolutionary advantage for male hunter-gathers and empathizing was advantageous for female caregivers. Studies of empathy consistently demonstrate that females are more empathic than males. ${ }^{51,70,71}$

Like intelligence, empathy has a genetic basis with an environmental overlay. Again, similar to intelligence, one's "empathy quotient" is the result of the interaction of nature and nurture. Harlow's classic work with monkeys demonstrated that monkeys who were not provided emotional warmth and tenderness after birth suffered significant negative effects. ${ }^{72}$ The monkeys did not know how to empathize with others or behave in a socially acceptable manner. Such a response also occurs in humans. Studies of Romanian children in overwhelmed and underfunded orphanages during the despotic rule of Nicolae Ceauşescu found tragic consequences to children. Minimal physical care and essentially no emotional care were provided, and many of the children died. Children who survived suffered severe emotional impairments. They were hostile to strangers, abusive to one another, and in many cases incapable of the most basic social interactions. Neuroscientists imaged the brains of the orphans and found reduced activity in the regions of the brain essential for emotional and social interaction. ${ }^{73}$

Recent cognitive science corroborates these findings through neurological investigations. There are a cluster of cells in the brain known as mirror neurons. These cells mirror the movements of others. When one sees another smile, the mirror neurons fire as if you were smiling. The same thing happens when one sees someone scowl, grimace, or cry. The Italian scientist who participated in discovering these mirror neurons, Giacomo Rizzolatti, et al. expressed it this way: "They allow us to grasp the minds of others, not through conceptual reasoning, but through direct stimulation; by feeling, not by thinking." 74 Empathy is wired as an instinct in the human brain; 
however, due to the plasticity of the brain, postnatal empathy development is influenced by environmental circumstances.

In summary, empathy has developed in human evolution as an instinct that has been naturally selected as a result of its ability to foster cooperative behavior and thus improve the ability to survive and thrive. Empathy is the capacity to enter into the emotional/cognitive world of another and thereby vicariously have a sense or appreciation of what he or she is experiencing, thus apprehending another's state of mind as if it were one's own. Experiences of joy are reciprocated with joy, distress with distress. There is emotional/cognitive congruence. Of particular importance and relevance to this discussion is that when distress is empathized with, helping behaviors are elicited..$^{50,52}$

\section{Empathy and Caring for Patients}

In 1963, Lief and Fox published an essay entitled "Training for 'Detached Concern' in Medical Students." 75 In it they observed that "it is generally agreed that it is proper to teach the concept of holistic medicine, in which the patient, rather than his liver, heart, or even his psyche, is the concern of the physician. This requires a set of special attitudes and skills generally termed empathy." They went on to describe empathy: "Empathy essentially involves an emotional understanding of the patient, 'feeling into' and being on the same wave length as the patient; at the same time, it connotes an awareness of enough separateness from the patient so that expert medical skills can be rationally applied to the patient's problems. The empathic physician is sufficiently detached or objective in his attitude toward the patient to exercise sound medical judgment and keep his equanimity, yet also has enough concern for the patient to give him sensitive, understanding care."

There is an expanding literature in the health professions on the importance of empathy in the doctor-patient relationship. ${ }^{76,77}$ A book by Jodi Halpern, a psychiatrist and philosopher, titled From Detached Concern to Empathy: Humanizing Medical Practice, ${ }^{78}$ has been widely reviewed and cited. ${ }^{79,80}$ In it, she discusses emotional reasoning in which the "empathizer [health professional] is able to resonate emotionally with, yet stay aware of, what is distinct about the patient's experience." Health professionals must be able to imagine how it feels to experience something that they are not directly experiencing. Halpern continues by saying there is a reason that empathy belongs in the doctor's office: "because it makes the care more effective."

Empathy has been repeatedly affirmed as an imperative for the humane physician in the doctorpatient relationship. Distinguished medical educator Edmund Pellegrino expressed it directly in his $\mathrm{Hu}$ manism and the Physician: "We must be dedicated to behaviors that reflect sincere concern and care for our patients, a caring that respects the freedom, dignity, and belief system of the individual, and a caring that manifests itself in a sensitive, non-humiliating and empathetic way of helping." ${ }^{\text {81 }}$ Noted medical educator Francis Peabody expressed it well in 1926 when he wrote that "the secret in the care of the patient is caring for the patient." ${ }^{\$ 2}$ Empathy and caring are conceptual twins. To take on the emotional/cognitive perspective of someone in need is empathy; to respond to such is to care.

Carol Gilligan and Nel Noddings have emphasized caring in their feminist approaches to ethics. ${ }^{83,84}$ Both have challenged the traditional emphasis, by predominantly male philosophers, of moral theory as grounded in accounts of a rules-based morality to ensure justice or fairness. Their claim is that morality is best understood in the context of human caring. Rosemary Tong contrasts the two approaches by suggesting that an ethics of justice emphasizes human separateness and individual rights, whereas an ethics of caring emphasizes human connectedness and communal relationships. ${ }^{85}$ An ethics of caring is one with an attitude rooted in receptivity, relatedness, and responsiveness. It is an empathy-based morality. The feminist approach, grounded in an empathic connectedness with others, more closely reflects a naturalistic approach to ethics, based in human evolutionary history.

The cardinal quality of the professional relationship is trust. Professions are professions because of the power differential that exists between them and those seeking their help. Such power, based in the professionals' knowledge and skills, requires that those seeking their help trust that health professionals will always use the power they possess in their patients' best interest. To do so requires an empathic disposition. Patients seek the care of a dentist to assist them in gaining the benefits of oral health. Embedded in patients' behavior is the expectation that they can trust the dentist to always act in doing what is best for their oral health - to always help and never to harm. Empathy on the part of the dentist is a prerequisite for 
such moral professional behavior. Professional ethics, as well as the golden rule, requires that dentists "treat their patients as they would want to be treated." Who would want to have less than appropriate treatment provided for them by a health professional from whom they seek care?

It is a truism that dentists are to be "good." An account of "the good dentist" would be one who diagnoses properly; plans treatment within the profession's standard of care; gains through effective communication a valid and informed consent; and implements agreed upon therapy in such a manner that it technically meets criteria for clinical quality. However, basic to all of these characteristics of a good dentist is the commitment to always act in the patient's best interest, even when it is in conflict with the dentist's own perceived best interest. Empirical evidence suggests that all dentists are not good dentists, at least not all of the time. While some may not be good dentists due to deficits in knowledge, problem-solving, or skill, it is also possible that their failure in professional goodness could be related to a deficiency of empathy - the inability to take on the perspective of their patients; to reverse roles; to respond to their patients' need in a truly caring manner; to treat patients as if their patients were them. Ultimately, understanding empathy's role in human behavior leads to an ethics of caring for health professionals.

\section{Implications for Dental Education}

There is increasing concern regarding the ethics of individuals practicing dentistry, ${ }^{86}$ with calls for emphasizing the teaching of professional ethics in dental curricula ${ }^{87}$ Ethics is moral philosophy; it is a discipline within the field of philosophy. Like epistemology and metaphysics, it is an intellectual discipline that can be taught. In a 1980 Hastings Center Report on teaching ethics in higher education, philosopher Daniel Callahan, then director of the center, and Sissela Bok identified a number of goals, which have been frequently cited, for teaching professional ethics. ${ }^{88}$ According to Callahan, professional ethics courses can 1) teach skills in moral reasoning and ethical analysis; 2) sensitize students to the moral dimensions of professional practice; 3 ) foster in students respect for disagreement and toleration of ambiguity; 4) explicate the moral responsibilities of becoming a member of the profession of dentistry; and 5) elicit a sense of moral obligation. The idea of eliciting a sense of moral obligation "is only to highlight with students an internal requirement of ethical thinking: that it calls us to act in the light of what we perceive to be right and good." ${ }^{89}$ Focusing specifically on improving moral behavior Callahan characterized as a "dubious goal." He considered it the responsibility of the moral training of children - not that of ethics instruction - to improve moral conduct, promote moral responsibility, and encourage the formation of morally desirable dispositions/virtues. It is important that professors articulate carefully the goals of professional ethics courses and assure students that improving their moral character is not the direct intention of such courses; such could be considered a form of social control or indoctrination. Rather, it is to permit students to understand how to apply their moral dispositions in the context of the professional life and work to which they aspire. Certainly, it can be hoped that courses in professional ethics will help students make better moral decisions than they would have if they had never had the experience of studying ethics. ${ }^{90}$

Not infrequently, students (and dentists) are skeptical about courses in professional ethics, as the view is expressed that such courses will not "make" students more ethical, that is, moral. There is reason for this skepticism as the general view of theorists is that the childhood and early teenage years are a critical time for the development of an empathy-mediated morality - a time when the pattern of one's moral disposition becomes established and stabilized. Hoffman, in his writings on moral development based on empathy, emphasizes the role of parents and teachers in building on the child's innate disposition for empathy. ${ }^{52}$ This is accomplished by teaching and modeling pro-social behavior in the context of a child's experience. (For a comprehensive discussion of the topic of empathy and moral development, see social psychologist Martin Hoffman's Empathy and Moral Development.) Ruston advances the idea further by arguing there is an "altruistic personality," a stable personality disposition to helping behavior that has its origins in empathy, which he defines as experiencing the emotional state of another. ${ }^{91}$ (For a thorough explication, see Altruism and Helping Behavior: Social, Personality, and Developmental Perspectives, J. Philippe Ruston and R.M. Sorrentino, eds.)

As empathy is an important quality for dentists to possess if they are to be moral (i.e., "good") practitioners, then it follows that measuring a candidate's 
ability to empathize with others could be an important admission criterion to the study of dentistry. Individuals who do not have the requisite cognitive or intellectual skills as measured by the Dental Admission Test (DAT) and/or previous academic performance or do not have basic perceptual-motor skills as measured by the DAT are not admitted to study dentistry. Given current understandings of empathy and its importance in helping behavior and the moral life, it is not unreasonable to expect that one's ability to empathize with others should be a considered criterion for entry to an educational program that focuses on helping behaviors. Measuring "emotional intelligence," arguably a correlate of empathy, has been advocated for medical school admission ${ }^{92}$ and reviewed as being potentially useful in the admissions process. ${ }^{93}$ In a recent commentary in Academic Medicine entitled "The Practice of Empathy," Harold Spiro, emeritus professor of medicine at Yale University, stated that "medical students should be selected as much by their character as by their knowledge."

Empathy is a quality that does not appear uniformly in society. Some individuals are more empathic than others. Similar to basic intelligence and perceptual motor skill, empathy can be measured. A number of instruments have been developed by social psychologists to measure empathy. Among the instruments that have been validated are the Hogan Empathy Scale, ${ }^{95}$ Davis's Interpersonal Reactivity Index, ${ }^{51}$ and Mehrabian's Balanced Emotional Empathy Scale. ${ }^{96}$

Hojat of the Jefferson Medical College has also developed an empathy instrument designed to be utilized specifically for physicians, the Jefferson Scale of Physician Empathy ${ }^{97}$ However, the instrument developed by Hojat focuses specifically on the cognitive or intellectual dimension of empathy to the exclusion of its emotional component. He explains his exclusion of the emotional component with his belief that the affective dimension of empathy is not as significant for health professionals since they need to maintain a "detached concern," that is, not allowing their emotions to influence their interaction with patients. Hojat's instrument has been used frequently in health professions education, including at least one study in dental education. ${ }^{98-101}$ Among the findings of these studies is that cognitive empathy actually declines during health professions education. Those studying this phenomenon have attributed this decline to a number of factors, including a lack of role models, the magnitude of learning required, time pressures, sleep deprivation, an intimidating educational environment, and the stressors of learning to interact with patients. ${ }^{102}$ Hojat and others have suggested that a variety of methods may be used to overcome this loss of cognitive empathy during health professions education through the exposure to appropriate role models, training students in interpersonal skills to improve the student-patient interaction, use of standardized patients, and improvement of the cultural environment of health professions education. ${ }^{93,103}$

In the context of this essay, it is important to distinguish between the intellectual/cognitive dimensions of empathy and the emotional. Davis has argued that the failure to distinguish between the two and their interactivity has contributed to considerable confusion in research and in the literature. ${ }^{51}$ Hojat and his colleagues' research focuses on the cognitive dimension of empathy, that is, the ability of one to apprehend, acknowledge, and intellectually identify with the circumstances of another. Research suggests that this dimension of empathy can be positively affected through such methods as indicated above-it can be maintained or even enhanced in the educational environment, even though the cited research suggests it is eroded. However, this evidence does not suggest that such instructional activities have an effect on the relatively stable emotional dimension of empathy or that which is core to an empathymediated morality as it has been discussed throughout this essay in the context of evolutionary biology and cognitive neuroscience. There is a significant difference between recognizing and appreciating the circumstance of another (intellectual empathy) and being motivated to care and to help (emotional empathy). An ethics of reciprocity ("doing to others as you would have others do to you") is an ethics of moral action, not solely cognition.

Dental educators should develop and utilize all of the tools available to ensure that students' intellectual empathy for their patients (and society) is not adversely affected during their education but is, in fact, enhanced. However, it is important to acknowledge that a student's core emotional empathy, the aspect of empathy that mediates a caring responsiveness to the needs of others, is a relatively stable personality characteristic developed in childhood. ${ }^{50,52,91}$ The thesis of this essay is that emotional empathy, as it has evolved in human evolution and developed existentially in the socialization of children, is an important determinant of moral behavior. Given this understanding, utilization of a psychological instrument that includes the assessment of emotional empathy could be a valuable tool in considering applicants for admission to dental 
school and to a caring profession dedicated to helping society gain the benefits of oral health.

\section{Summary and Conclusions}

Contemporary understanding of evolutionary biology and human neuroscience are transforming understanding of human behavior, specifically moral behavior. As a consequence, ethics is beginning to be understood as having an empirical science dimension - a science base that is challenging many of the philosophical perspectives that have been held for centuries. Understanding the ultimate causation of human behavior is rooted in humanity's evolutionary history. Evolutionary biology indicates that humans developed the trait of empathy as a result of the parental bonding that occurred as a result of an extended infancy of human offspring. From this, an empathic disposition toward family and others evolved. An appreciation of the needs of others based in empathizing resulted in helping behaviors, behaviors that would be reciprocated if a cooperative relationship was to be maintained. Such cooperation enhanced survival and reproduction. Morality evolved as an empathybased system of fair cooperation.

Empathy is an important attribute for an individual entering a helping profession such as dentistry. It is of equivalent importance to intelligence and perceptual motor skill. Empathy varies in the population as do these other two important human attributes and can be measured as well. Dental educators should consider assessing empathy in the admissions process, and leaders in dental education should work to create colleges of dentistry that are moral communities in which caring is a cardinal characteristic.

\section{REFERENCES}

1. Audi R, ed. Cambridge dictionary of philosophy. Cambridge: Cambridge University Press, 1995.

2. Tillich P. Morality and beyond. New York: Harper and Row, 1962.

3. Arnhart L. Darwinian natural right: the biological ethics of human nature. Albany: State University of New York Press, 1998.

4. Wright R. The moral animal: why we are the way we are - the new science of evolutionary psychology. New York: Pantheon, 1994.

5. Pinker S. The blank slate: the modern denial of human nature. New York: Viking, 2002.

6. Rachels J. Created from animals: the moral implications of Darwinism. Oxford: Oxford University Press, 1991.

7. Nitecki MH, Nitecki DV. Evolutionary ethics. Albany: State University of New York Press, 1993.
8. Alexander RD. The biology of moral systems. Hawthorne, NY: Aldine De Gruyter, 1987.

9. Ruse M. Taking Darwin seriously. Amherst, NY: Prometheus Press, 1998.

10. Ridley M. The origins of virtue. New York: Penguin Books, 1997.

11. Katz LD, ed. Evolutionary origins of morality: crossdisciplinary perspectives. Thorverton, UK: Imprint Academic, 2000.

12. Hauser MD. Moral minds: how nature designed our universal sense of right and wrong. New York: HarperCollins, 2006.

13. Aristotle. Nicomachean ethics (350 B.C.E.). Wellden JEC, trans. Buffalo: Prometheus Press, 1988.

14. Aquinas T. The Summa Theologica of St. Thomas Aquinas (1265-1274). Notre Dame: Christian Classics, 1981.

15. Kenny A, ed. The Oxford history of western philosophy. Oxford: Oxford University Press, 1994.

16. Hume D. An enquiry concerning human understanding (1748). Buffalo: Prometheus Press, 1988.

17. Hutcheson F. Essay on the nature and conduct of the passions and affections and illustrations upon the moral sense (1728). Gainesville, FL: Scholars' Facsimiles and Reports, 1969.

18. Smith A. The theory of moral sentiments (1759). Haakonssen K, ed. New York: Cambridge University Press, 2002.

19. Darwin C. The origin of species: by means of natural selection (1859). Buffalo: Prometheus Press, 1991.

20. Darwin C. The descent of man: and selection in relation to sex (1871). Princeton: Princeton University Press, 1981.

21. Hobbes T. Leviathan (1651). Buffalo: Prometheus Press, 1988.

22. Kant I. Fundamental principles on the metaphysics of morals (1785). Abbot TK, ed. Buffalo: Prometheus Press, 1988.

23. Wilson EO. Sociobiology: the new synthesis. Cambridge: Harvard University Press, 1975.

24. Buss DM. Evolutionary psychology: the new science of the mind. Boston: Allyn and Bacon, 1999.

25. Diamond J. The third chimpanzee: the evolution and future of the human animal. New York: Harper Perennial, 1992.

26. Crawford C, Krebs DL. Handbook of evolutionary psychology: ideas, issues, and applications. Mahwah, NJ: Lawrence Erlbaum Associates, 1998.

27. Dawkins R. The selfish gene. New York: Oxford University Press, 1976.

28. de Waal F. Primates and philosophers: how morality evolved. Princeton: Princeton University Press, 2006.

29. de Waal F. Chimpanzee politics: power and sex among apes. Baltimore: Johns Hopkins University Press, 1989.

30. de Waal F. Good natured: the origins of right and wrong in humans and other animals. Cambridge: Harvard University Press, 1996.

31. de Waal F. Our inner ape: a leading primatologist explains why we are who we are. New York: Riverhead Books, 2005.

32. Jones S, Martin R, Pilbeam D, eds. The Cambridge encyclopedia of human evolution. Cambridge, UK: Cambridge University Press, 1992.

33. Ruse M, Travis J, eds. Evolution: the first four billion years. Cambridge: Belknap Press of Harvard University Press, 2009. 
34. Hamilton WD. The genetical evolution of social behavior, I and II. J Theor Biol 1964;7(1):1-52.

35. Trivers R. The evolution of reciprocal altruism. Q Rev Biol 1971;4:35-57.

36. Axelrod R. The evolution of cooperation. New York: Basic Books, 1984.

37. Barash DP. The survival game: how game theory explains the biology of cooperation and competition. New York: Times Books, 2003.

38. Allman WF. The stone age present: how evolution has shaped modern life-from sex, violence, and language to emotions, morals, and communities. New York: Touchstone, 1994.

39. Tooby J, Cosmides L. Psychological foundations of culture. In: Barkow J, Cosmides L, Tooby J, eds. The adapted mind. New York: Oxford University Press, 1992.

40. Greek polytheism: "And may I, being of sound mind, do to others as I would that they should do to me." Plato's Laws, Book XI, 400 BCE.

41. Judaism: "Thou shalt love thy neighbor as thyself." Leviticus 19:18.

42. Christianity: "And as ye would that men should do to you, do ye also to them likewise." Luke 6:31.

43. Islam: "None of you believes until he wishes for his brother what he wishes for himself." Al-Nawawi's Forty Hadiths, Number 13.

44. Hinduism: "This is the sum of duty: do not do to others what would cause pain if done to you." Mahabharata 5:1517.

45. Confucianism: "Do not do to others what you do not want them to do to you." Analects 15:23.

46. Buddhism: "Hurt not others in ways that you yourself would find hurtful." Udana-Varga 5:18.

47. Gert B. The moral rules: a new foundation for morality. New York: Harper and Row, 1973.

48. Gert B. Common morality: deciding what to do. New York: Oxford University Press, 2004.

49. de Waal F. Putting the altruism back into altruism: the evolution of empathy. Annu Rev Psychol 2008;59:279-300.

50. Batson CD. The altruism question: toward a social psychological answer. Hillsdale, NJ: Lawrence Erlbaum, 1991.

51. Davis MH. Empathy: a social psychological approach. Boulder: Westview Press, 1996.

52. Hoffman ML. Empathy and moral development: implications for caring and justice. Cambridge, UK: Cambridge University Press, 2000.

53. Decety J, Ickes W, eds. The social neuroscience of empathy. Cambridge, MA: MIT Press, 2009.

54. Slote M. The ethics of care and empathy. New York: Routledge, 2007.

55. Greek-English dictionary. At: www.kypros.org/cgi-bin/ lexicon/. Accessed: August 24, 2009.

56. Hojat M. Empathy in patient care: antecedents, development, measurement, and outcomes. New York: Springer, 2007.

57. Freud S. Jokes and their relation to the unconscious (1905). Strachey J, trans. and ed.; with a biographical introduction by Peter Gay. New York: Norton, 1989.

58. Rogers CR. Client centered therapy: its current practice, implications, and theory. Boston: Houghton Mifflin, 1951.

59. Salovey P, Mayer JD. Emotional intelligence. Imagination Cognition Personality 1990;9:185-211.
60. Goleman D. Emotional intelligence: why it can matter more than IQ. New York: Bantam Books, 1995.

61. Masserman JH, Wechkin S, Terris W. "Altruistic" behavior in Rhesus monkeys. Am J Psychol 1964;121:584-5.

62. O'Connell SM. Empathy in chimpanzees: evidence for theory of mind? Primates 1995;36:397-410.

63. de Waal F. The ape and sushi master: cultural reflections of a primatologist. New York: Basic Books, 2001.

64. Acebo C, Thoman EB. Role of infant crying in the early mother-infant dialogue. Physiol Behav 1995;57:541-7.

65. Hoffman ML. Is altruism part of human nature? J Pers Soc Psychol 1981;40:121-37.

66. Baron-Cohen S. Mindblindness: an essay on autism and theory of mind. Cambridge, MA: MIT Press, 1995.

67. Chakrabarti B, Dudbridge F, Kent L, Wheelwright S, Hill-Cawthorne G, Allison C, et al. Genes related to sex steroids, neural growth, and social-emotional behavior are associated with autistic traits, empathy, and Asperger syndrome. Autism Res 2009;2:157-77.

68. Chen Q, Panksepp JB, Lahvis GP. Empathy is moderated by genetic background in mice. PLos ONE 4(2):e4387. doi:10.1371/journal.pone.0004387, February 11, 2009.

69. Baron-Cohen S. Autism: the empathizing-systemizing (E-S) theory. Ann N Y Acad Sci 2009;1156:68-70.

70. Baron-Cohen S. The essential difference: men, women, and the extreme male brain. New York: Penguin Press Science, 2004

71. Hoffman ML. Sex differences in empathy and related behaviors. Psychol Bull 1997;84:712-22.

72. Harlow H. Love in infant monkeys. Sci Am 1959; 200(June):68-74.

73. Chugani H, Behen M, Muzik O, Juhasz C, Nagy F, Chugani DC. Local brain functional activity following early deprivation: a study of post-institutionalized Romanian orphans. Neuroimage 2001;14:1290-301.

74. Rizzolatti G, Sinigaglia C, Anderson F. Mirrors in the brain: how our minds share actions, emotions, and experience. New York: Oxford University Press, 2008.

75. Lief HI, Fox RC. Training for "detached concern" in medical students. In: Lief HI, Lief VF, Lief NR, eds. The psychological basis of medical practice. New York: Harper and Row, 1963.

76. Spiro H, McCrea-Curnen MG, Peschel E, St. James D. Empathy and the practice of medicine: beyond pills and the scalpel. New Haven: Yale University School of Medicine, 1993.

77. More ES, Milligan MA, eds. The empathic practitioner: empathy, gender, and medicine. New Brunswick, NJ: Rutgers University Press, 1994.

78. Halpern J. From detached concern to empathy: humanizing medical practice. New York: Oxford University Press, 2001.

79. Charon R. From detached concern to empathy: humanizing medical practice. Book review. J Health Pol Policy Law 2003;28.

80. Cassell E. From detached concern to empathy: humanizing medical practice. N Engl J Med 2002;347:1628-9.

81. Pellegrino ED. Humanism and the physician. Knoxville: University of Tennessee Press, 1979.

82. Peabody FW. The care of the patient. JAMA $1927 ; 88$ : 877-82. 
83. Gilligan C. In a different voice: psychological theory and women's development. Cambridge: Harvard University Press, 1982.

84. Noddings N. Caring: a feminine approach to ethics and moral education. Berkeley and Los Angeles: University of California Press, 1984.

85. Tong R. The ethics of care: a feminist virtue ethics of care for healthcare practitioners. J Med Philos 1998;23:131-52.

86. Bertolami CN. Why our ethics curricula don't work. J Dent Educ 2004;68(4):414-25.

87. Koerber A, Botto RW, Pendleton DD, Albazzaz MB, Doshi SJ, Rinando VA. Enhancing ethical behavior: views of students, administrators, and faculty. J Dent Educ 2005;69(2):213-24

88. Callahan D, Bok S, eds. Ethics teaching in higher education. New York: Plenum Press, 1980.

89. Maxwell B. Professional ethics education: studies in compassionate empathy. Dordrecht, The Netherlands: Springer, 2008.

90. Macaulay JR, Berkowitz L, eds. Altruism and helping behavior. New York: Academic Press, 1970.

91. Ruston JP. The altruistic personality. In: Ruston JP, Sorrentino RM, eds. Altruism and helping behavior: social, personality, and developmental perspectives. Hillsdale, NJ: Lawrence Erlbaum Associates, 1981:251-66.

92. Carrothers RM, Gregory SW Jr, Gallagher TJ. Measuring emotional intelligence of medical school applicants. Acad Med 2000;75:456-63.

93. Elam C. Use of "emotional intelligence" as one measure of medical school applicants' noncognitive characteristics. Acad Med 2000;75:445-6.

94. Spiro H. Commentary: the practice of empathy. Acad Med 2009;84:1177-9.
95. Hogan R. Development of an empathy scale. J Consult Clin Psychol 1969;33:307-16.

96. Mehrabian A. Manual for the balanced emotional empathy scale (BEES), 1996. Available from Albert Mehrabian, 1130 Alta Mesa Road, Monterey, CA 93940.

97. Hojat M, Mangione S, Nasca TJ, Cohen MJM, Gonnella JS, Erdmann JB, Veloski J. The Jefferson scale of physician empathy: development and preliminary psychometric data. Emotional Psychol Meas 2001;61:349-65.

98. Hojat M, Gonnella J, Nasca T, Mangione S, Vergare M, Magee M. Physician empathy: definition, components, measurement, and relationship to gender and specialty. Am J Psychiatry 2002;159:1563-9.

99. Hojat M, Gonnella J, Nasca T, Mangione S, Veloski J, Magee M. The Jefferson scale of physician empathy: further psychometric data and differences by gender and specialty at item level. Acad Med 2002;77:S58-S80.

100. Hojat M, Mangione S, Nasca T, Rattner J, Erdmann JB, Gonnella JS, Magee M. An empirical study of the decline of empathy in medical school. Med Educ 2004;38:934-41.

101. Sherman JJ, Cramer A. Measurement of changes in empathy during dental school. J Dent Educ 2005;69(3):338 45.

102. Hojat M, Vergare MJ, Maxwell K, Brainard G, Herrine SK, Isenberg GA, et al. The devil is in the third year: a longitudinal study of erosion of empathy in medical school. Acad Med 2009;84(9):1182-91.

103. Hojat M. Ten approaches for enhancing empathy in health and human services. J Health Hum Services 2009; Spring:412-50. 